\title{
PERAN LEMBAGA KEUANGAN MIKRO TERHADAP EKSISTENSI USAHA MIKRO (STUDI PADA NASABAH PD BPR BANK SLEMAN)
}

\author{
Dila Damayanti \\ Sekolah Tinggi Ilmu Ekonomi Widya Wiwaha \\ Yogyakarta \\ E-mail: dhamay_dd@yahoo.com
}

\begin{abstract}
Abstrak
Penelitian berjudul "Peran Lembaga Keuangan Mikro untuk Usaha Mikro (studi nasabah PD BPR Bank Sleman di Kabupaten Sleman)" bertujuan untuk menganalisis peran lembaga keuangan mikro dalam keberadaan usaha mikro di Daerah Istimewa Yogyakarta dengan variabel dependen (Y) adalah Mikro Keberadaan Bisnis yang ditunjukkan oleh kinerja Perusahaan Mikro dan variabel independen (X) terdiri dari Fasilitator Manajemen (X1), Fasilitator Pemasaran (X2) dan variabel Fasilitator Keuangan (X3). Pengumpulan data diperoleh melalui wawancara dengan instrumen kuesioner kepada nasabah PD BPR Bank Sleman di Kabupaten Sleman. Pengujian hipotesis menggunakan uji validitas, uji reliabilitas, uji regresi linier berganda dan uji determinasi dengan bantuan perangkat lunak SPSS. Berdasarkan uji regresi berganda, hasil untuk ketiga variabel independen memiliki pengaruh terhadap keberadaan usaha mikro, tetapi pengaruhnya tidak terlalu kuat karena nilai $\mathrm{R}^{2}$ hanya 0.589 . Sedangkan berdasarkan hasil uji parsial masing-masing variabel independen, hasil untuk Variabel Fasilitator adalah variabel yang memiliki kontribusi terbesar dengan nilai koefisien 2.260.
\end{abstract}

Kata kunci: Bisnis Mikro, Lembaga Keuangan Mikro, Keberadaan Bisnis

\section{Abstract}

The study entitled "The Role of Microfinance Institutions for Micro Business (study of PD BPR Bank Sleman customers in Sleman Regency)" aims to analyze the role of microfinance institutions in the existence of micro businesses in the Yogyakarta Special Region with the dependent variable $(Y)$ is Business Existence Micro indicated by Micro Enterprise performance and independent variable $(X)$ consists of Management Facilitator (X1), Marketing Facilitator (X2) and Finance Facilitator (X3) variables. Data collection was obtained through interviews with questionnaire instruments to PD BPR Bank Sleman customers in Sleman Regency. Hypothesis testing uses validity test, reliability test, multiple linear regression test and determination test with the help of SPSS software. Based on multiple regression tests, the results for the three independent variables have an influence on the existence of microbusinesses, but the effect is not too strong because the $R^{2}$ value is only 0.589. While based on the partial test results of each independent variable, the results for the Facilitator Variable are the variables that have the greatest contribution with a coefficient value of 2.260 .

Keywords: Micro Business, Microfinance Institutions, Business Existence

Article History: $\quad$ Received 29 Nov 2019 Revised 16 Des 2019 Accepted 26 Des 2019 


\section{PENDAHULUAN}

Usaha Mikro Kecil dan Menengah (UMKM) terbukti sebagai penggerak utama sektor riil yang berpengaruh langsung terhadap pertumbuhan ekonomi nasional. Kementerian Koperasi dan UKM RI melaporkan bahwa secara jumlah unit, UMKM memiliki pangsa sekitar 99,99\% (62.9 juta unit) dari total keseluruhan pelaku usaha di Indonesia (2017), sementara usaha besar hanya sebanyak $0,01 \%$ atau sekitar 5400 unit. Usaha Mikro menyerap sekitar 107,2 juta tenaga kerja $(89,2 \%)$, Usaha Kecil 5,7 juta $(4,74 \%)$, dan Usaha Menengah 3,73 juta $(3,11 \%)$, sementara Usaha Besar menyerap sekitar 3,58 juta jiwa. Artinya secara gabungan UMKM menyerap sekitar 97\% tenaga kerja nasional, sementara Usaha Besar hanya menyerap sekitar 3\% dari total tenaga kerja nasional. (https://www.ukmindonesia.id/baca$\operatorname{artikel/62).~}$

Pada kenyataannya, perkembangan UMKM umumnya masih mengalami berbagai masalah dan belum sesuai dengan yang diharapkan. Masalah yang hingga kini masih menjadi kendala dalam pengembangan usaha UMKM adalah keterbatasan modal yang dimiliki dan sulitnya UMKM mengakses sumber permodalan. Hidayat (2006) dalam penelitiannya yang berjudul "Pengaruh Lembaga Keuangan Mikro terhadap Prestasi Industri Kecil Rumah Tangga di Kabupaten Merangin (Studi kasus di Kecamatan Bangko, Kabupaten Merangin)" dengan hasil variabel yang berpengaruh signifikan terhadap industri kecil rumah tangga yaitu Pembinaan, Agunan dan kredit.

Penelitian dengan variabel berbeda yang dilakukan oleh Karay (2012) dengan judul "Analisis Peran Lembaga Keuangan Mikro terhadap Pemberdayaan Usaha Mikro Kecil di Kabupaten Jayapura (Studi kasus BPR Nusa Intim Cabang Sentani)". Hasil penelitian menunjukkan bahwa variabel keuangan dan pemasaran mempunyai peran atau pengaruh yang signifikan dan positif terhadap pemberdayaan UMK, sedangkan variabel produksi dan pendampingan tidak berperan atau tidak berpengaruh terhadap pemberdayaan UMK. Hasil analisis korelasi, hanya ada dua variabel yang berhubungan secara nyata terhadap peran LKM dalam pemberdayaan UKM yaitu variabel keuangan dan variabel pemasaran. Hubungan yang lemah ditunjukkan antara variabel produksi dan variabel pendampingan dengan peran LKM dalam pemberdayaan UMK dimana nilai koefisien korelasi masing-masing variabel mendekati nol.

Sebagian besar UMKM merupakan usaha skala mikro yang mayoritas belum tersentuh oleh lembaga keuangan yang disebabkan kendala teknis, maka sudah sepantasnya bahwa sektor usaha mikro menjadi perhatian sekaligus pasar sasaran (target market) yang potensial bagi Lembaga Keuangan Mikro (LKM). Banyaknya pelaku usaha mikro yang belum tersentuh oleh pihak perbankan menjadikan sebuah peluang bagi Lembaga Keuangan Mikro bank maupun nonbank. Begitu pula usaha mikro yang berada di Kabupaten Sleman, dari 27.000 pelaku usaha mikro yang ada di Kabupaten Sleman hanya 25\% yang sudah terhubung dengan pihak bank. Tentunnya hal ini bisa menjadi peluang besar bagi pihak Lembaga Keuangan Mikro yang berada di Kabupaten Sleman. PD BPR Bank Sleman yang merupakan salah satu Badan Usaha Milik Daerah tidak mau kehilangan kesempatan untuk merangkul pelaku usaha mikro yang ada di Kabupaten Sleman untuk memperoleh layanan kredit usaha mikro, apalagi berdasarkan data pertumbuhan perekonomian daerah PD BPR Bank Sleman telah mampu meningkatkan pertumbuhan perekonomian daerah. Pada 2010, perekonomian daerah tumbuh 4,53\%, 
menjadi 5,19\% pada tahun 2011, kemudian naik menjadi $5,45 \%$ pada tahun 2012 , pada tahun 2013 naik menjadi 5,70\%, sedangkan di tahun 2014 pertumbuhan perekonomian sudah mencapai $3,81 \%$.

Berdasarkan paparan di atas, maka peneliti merumuskan permasalahan yang dianalisa dalam penelitian terkait peran Lembaga Keuangan Mikro (LKM) terhadap eksistensi Usaha Mikro, yaitu bagaimana pengaruh peran fasilitator manajemen, fasilitator pemasaran, dan fasilitator keuangan terhadap eksistensi usaha mikro.

\section{LANDASAN TEORI}

Lembaga Keuangan Mikro adalah suatu lembaga keuangan non bank yang didirikan dengan tujuan untuk membantu pengembangan usaha-usaha kecil menengah dengan pemberian pinjaman modal. Lembaga ini didirikan agar terciptanya perekonomian rakyat yang tangguh, berdaya saing tinggi, dan mandiri yang kemudian memberi dampak terhadap peningkatan perekonomian nasional. Lembaga Keuangan Mikro yang selanjutnya disingkat LKM juga merupakan lembaga keuangan yang khusus didirikan untuk pemberdayaan masyarakat, baik melalui pinjaman atau pembiayaan dalam usaha skala mikro kepada anggota dan masyarakat, pengelolaan simpanan, maupun pemberian jasa konsultasi pengembangan usaha yang tidak sematamata mencari keuntungan.

Keberadaan LKM menjadi faktor kritikal dalam usaha penanggulangan kemiskinan yang efektif. Menurut Krishnamurti (2003) sebagaimana dikutip dalam Ashari (2006:153) menyebutkan peningkatan akses dan pengadaan sarana penyimpanan, pembiayaan, dan asuransi yang efisien dapat membangun keberdayaan kelompok miskin dan peluang mereka untuk keluar dari kemiskinan melalui: tingkat konsumsi yang lebih pasti dan tidak berfluktuasi, mengelola risiko dengan lebih baik, secara bertahap memiliki kesempatan untuk membangun aset, mengembangkan kegiatan usaha mikro, menguatkan kapasitas perolehan pendapatan, serta meningkatkan kesejahteraan hidup yang lebih baik,

Tanpa akses yang cukup pada LKM, hampir seluruh rumah tangga miskin bergantung pada kemampuan pembiayaan sendiri yang sangat terbatas atau pada lembaga keuangan informal seperti renternir, tengkulak, atau pelepas uang. Kondisi ini membatasi kemampuan kelompok UMKM berpartisipasi dan mendapat manfaat dari peluang pembangunan. Ashari (2006: 152) menyatakan bahwa "Potensi yang dapat diperankan LKM dalam memacu pertumbuhan ekonomi sangat besar."

Tabel 1. Kriteria UMKM menurut UU No. 20 Tahun 2008

\begin{tabular}{|c|l|l|l|}
\hline \multirow{2}{*}{ No } & \multirow{2}{*}{ Uraian } & \multicolumn{2}{|c|}{ Kriteria } \\
\cline { 3 - 4 } & & Asset & \multicolumn{1}{|c|}{ Omzet } \\
\hline \multirow{2}{*}{$\mathbf{1}$} & Usaha & Maks. & Maks. \\
& Mikro & 50 juta & 300 juta \\
\hline \multirow{2}{*}{$\mathbf{2}$} & Usaha & $>50$ juta & $>300$ \\
& Kecil & -500 & juta $-2,5$ \\
& & juta & $\mathrm{M}$ \\
\hline \multirow{3}{*}{$\mathbf{3}$} & Usaha & $>500$ & $>2,5 \mathrm{M}-$ \\
& Menengah & $\begin{array}{l}\text { juta }- \\
\text { jug }\end{array}$ & $50 \mathrm{M}$ \\
\hline
\end{tabular}

Sumber : www.depkop.go.id

Modal merupakan salah satu kunci penting dalam melakukan kegiatan bisnis. Tanpa adanya modal yang cukup, maka bisnis tidak dapat berjalan dengan baik. Demikian halnya dengan usaha kecil, untuk dapat membangun, menjalankan dan mengembangkan usahanya, usaha mikro memerlukan modal tertentu. Guna mencukupi modal yang dibutuhkan, pemerintah melalui program kerja berupaya membantu dengan menetapkan berbagai kebijakan yang berpihak pada usaha mikro. Program untuk membantu usaha mikro dalam hal permodalan tidak hanya dilakukan oleh pemerintah tetapi juga oleh lembaga swadaya masyarakat seperti koperasi simpan pinjam, LSM microfinance, dan sebagainya. 
Banyaknya lembaga yang memberikan pembiayaan kepada Usaha Mikro seharusnya dapat meminimalisir permasalahan Usaha Mikro terkait permodalan atau pembiayaan. Namun, pembiayaan yang diperoleh dari lembaga pembiayan tersebut belum tentu dapat dipergunakan secara optimal oleh Usaha
Mikro. Oleh sebab itu diperlukan peranan lembaga pembiayaan selain sebagai sarana penyedia dana, juga sebagai fasilitator usaha, yaitu fasilitator dalam bidang manajemen, fasilitator dalam bidang pemasaran serta fasilitator dalam bidang keuangan.

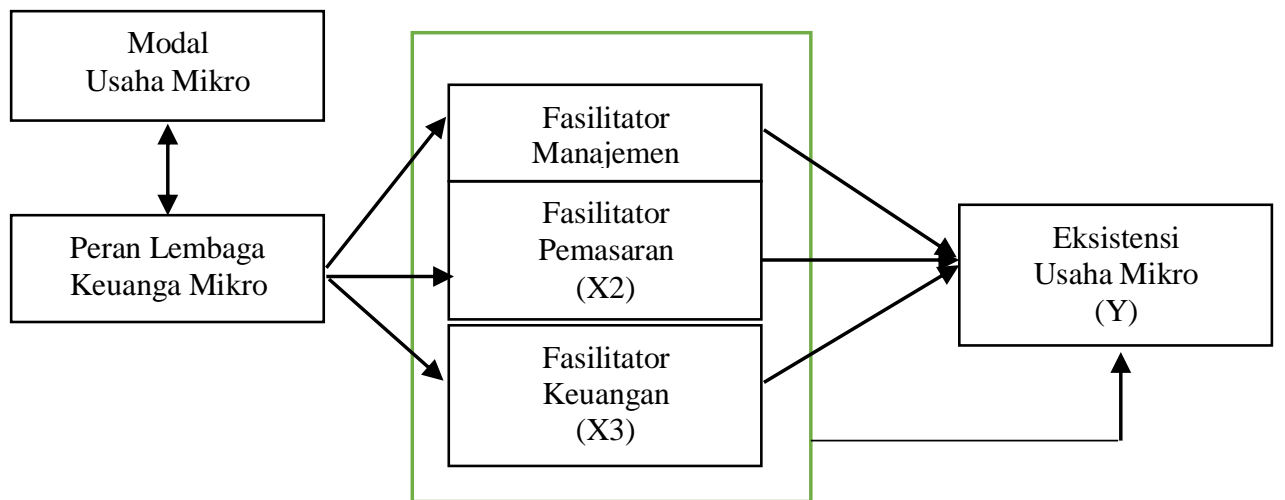

Gambar 1. Kerangka Konseptual Penelitian

Hipotesis penelitian yang dikembangkan untuk menjawab permasalahan dalam penelitian ini adalah:

H1 : Fasilitator Manajemen berpengaruh signifikan terhadap eksistensi Usaha Mikro.

H2 : Fasilitator Pemasaran berpengaruh signifikan terhadap eksistensi Usaha Mikro.

H3 : Fasilitator Keuangan berpengaruh signifikan terhadap eksistensi Usaha Mikro.

H4 : Fasilitator Manajemen, Fasilitator Pemasaran, dan Fasilitator Keuangan berpengaruh signifikan terhadap eksistensi Usaha Mikro.

\section{METODE PENELITIAN}

Penelitian ini merupakan penelitian deskriptif tentang peran LKM terhadap eksistensi Usaha Mikro di Kabupaten Sleman. Teknik pelaksanaan dari penelitian ini menggunakan metode survey, yaitu penelitian yang mengambil sampel dari suatu populasi dengan menggunakan kuesioner sebagai alat bantu untuk mengumpulkan data (Singarimbun dan Effendi, 2009).

Penentuan sampel dilakukan dengan menggunakan metode purposive sampling yaitu teknik penentuan sampel berdasarkan apa yang dipertimbangkan bahwa unit atau unsur penarikan sampel tersebut dapat membantu menjawab pertanyaan-pertanyaan riset yang sedang dikerjakan (Kinnear dan Taylor, 2003). Dalam penelitian ini, sampel yang diambil sebanyak 100 nasabah PD BPR Bank Sleman yang merupakan pelaku Usaha Mikro di wilayah Kabupaten Sleman yang telah menjadi nasabah kredit Usaha Mikro lebih dari 1 tahun.

Variabel dalam penelitian dibedakan menjadi dua, yaitu variabel independen dan variabel dependen. Variabel dependen yang digunakan dalam penelitian adalah Eksistensi Usaha Mikro (Y), sedangkan variabel independen yang digunakan dalam adalah Fasilitator Manajemen (X1), Fasilitator Pemasaran (X2), dan Fasilitator Keuangan 
(X3). Definisi dan batasan variabel yang digunakan adalah sebagai berikut:

a. Eksistensi Usaha Mikro (Y)

Eksistensi menurut Kamus Besar Bahasa Indonesia dapat diartikan sebagai keberadaan. Dalam penelitian ini yang dimaksud dengan eksistensi Usaha Mikro adalah keberadaan Usaha Mikro atau dapat diartikan sebagai keberlanjutan Usaha Mikro dengan indikator kinerja Usaha Mikro.

b. Fasilitator Manajemen (X1)

Fasilitator manajemen adalah lembaga keuangan mikro mendampingi dan membantu usaha mikro dalam aktivitas manajemen yang ditunjukkan dengan indikator: Pengurusan izin usaha, Pengurusan kredit/ pinjaman, Pelatihan pengelolaan SDM, Pelatihan penggunaan IT, Manajemen usaha lebih bagus, Pembuatan rencana bisnis.

c. Fasilitator Pemasaran (X2)

Fasilitator pemasaran adalah lembaga keuangan mikro mendampingi dan membantu usaha mikro dalam memperluas pasar dan pemasaran produk yang ditunjukkan dengan indikator:Pencarian pelanggan, Penyertaan dalam pameran, Promosi pada pihak lain, Penyediaan tempat usaha, Pendampingan inovasi produk.

d. Fasilitator Keuangan (X3)

Fasilitator keuangan adalah lembaga keuangan mikro mendampingi dan membantu usaha mikro dalam mengelola keuangan lebih efektif yang ditunjukkan dengan indikator: Pembuatan pembukuan, Pembuatan laporan keuangan, Pelatihan perpajakan, Pendampingan pengelolaan dana pinjaman.

Uji validitas digunakan untuk memilih di antara item-item pernyataan yang relevan untuk dianalisis dengan melakukan uji korelasi antara skor item pernyataan dan skor total dari pernyataan tersebut. Kriteria penilaian uji validitas sebagai berikut: a. Apabila $\mathrm{r}$ hitung $>\mathrm{r}$ tabel (pada taraf signifikansi 5\%), maka item kuisioner tersebut valid.

b. Apabila $\mathrm{r}$ hitung $<\mathrm{r}$ tabel (pada taraf signifikansi $5 \%$ ), maka item kuisioner tersebut tidak valid.

Peneliti dapat mengevaluasi instrumen penelitian berdasarkan perspektif dan teknik yang berbeda, tetapi pertanyaan mendasar untuk mengukur reliabilitas data adalah "bagaimana konsistensi data dikumpulkan" (Indriantoro \& Supomo, 2014). Pengujian reliabilitas terhadap daftar pernyataan yang diuji dikatakan reliabel jika nilai cronbach alpha $\geq 0.6$.

Model regresi yang digunakan dalam penelitian dapat diformulasikan sebagai berikut:

$$
Y=a+b 1 X 1+b 2 X 2+b 3 X 3
$$

Dimana :

$\mathrm{Y}=$ Eksistensi Usaha Mikro

$\mathrm{a}=$ Koefisien Konstanta

b1, b2, b3 = Koefisien Regresi

$\mathrm{X}_{1}=$ Fasilitator Manajemen

$\mathrm{X}_{2}=$ Fasilitator Pemasaran

$\mathrm{X}_{3}=$ Fasilitator Keuangan

Uji t digunakan untuk mengetahui pengaruh fasilitator manajemen $\left(\mathrm{X}_{1}\right)$, fasilitator pemasaran $\left(\mathrm{X}_{2}\right)$, dan fasilitator keuangan $\left(\mathrm{X}_{3}\right)$ secara parsial atau individual terhadap eksistensi Usaha Mikro (Y). Kriteria pengujian yang digunakan sebagai berikut:

a. Hipotesis diterima jika nilai probabilitas $\mathrm{t}($ signifikan $\mathrm{t}) \leq \alpha$

b. Hipotesis ditolak jika nilai probabilitas $t$ $(\operatorname{signifikan} \mathrm{t}) \geq \alpha$

Uji $F$ digunakan untuk menguji hipotesis yang menyatakan terdapat fasilitator manajemen $\left(\mathrm{X}_{1}\right)$, fasilitator pemasaran $\left(\mathrm{X}_{2}\right)$, dan fasilitator keuangan $\left(\mathrm{X}_{3}\right)$ secara keseluruhan atau simultan terhadap eksistensi Usaha Mikro (Y). Kriteria pengujian yang digunakan sebagai berikut: 
a. Hipotesis diterima jika nilai probabilitas $\mathrm{F}($ Signifikan $\mathrm{F}) \leq \alpha$

b. Hipotesis ditolak jika nilai probabilitas $\mathrm{F}$ (Signifikan F) $\geq \alpha$

Koefisien determinasi $\left(\mathrm{R}^{2}\right)$ digunakan untuk mengukur seberapa jauh kemampuan model dalam menerangkan variasi variabel dependen. Koefisien determinasi $\left(\mathrm{R}^{2}\right)$ dinyatakan dalam persentase. Nilai $\mathrm{R}^{2}$ berkisar antara $0<\mathrm{R}^{2}<1$.

\section{HASIL DAN PEMBAHASAN}

Berdasarkan uji validitas dalam penelitian ini diperoleh hasil pengujian seperti yang tertuang dalam Tabel 2 . Hasil tersebut menunjukkan nilai $r$ Hitung > r Tabel yang artinya setiap item pertanyaan dalam kuesioner valid.

Tabel 2. Hasil Uji Validitas

\begin{tabular}{|l|l|l|l|}
\hline $\begin{array}{c}\text { Item } \\
\text { Pertanyaan }\end{array}$ & r Hitung & r Tabel & Keterangan \\
\hline X11 & 0.636 & 0.1966 & VALID \\
\hline X12 & 0.514 & 0.1966 & VALID \\
\hline X13 & 0.315 & 0.1966 & VALID \\
\hline X14 & 0.288 & 0.1966 & VALID \\
\hline X15 & 0.636 & 0.1966 & VALID \\
\hline $\mathrm{X} 16$ & 0.551 & 0.1966 & VALID \\
\hline $\mathrm{X} 21$ & 0.701 & 0.1966 & VALID \\
\hline $\mathrm{X} 22$ & 0.407 & 0.1966 & VALID \\
\hline $\mathrm{X} 23$ & 0.701 & 0.1966 & VALID \\
\hline $\mathrm{X} 24$ & 0.474 & 0.1966 & VALID \\
\hline $\mathrm{X} 25$ & 0.270 & 0.1966 & VALID \\
\hline $\mathrm{X} 31$ & 0.816 & 0.1966 & VALID \\
\hline $\mathrm{X} 32$ & 0.804 & 0.1966 & VALID \\
\hline $\mathrm{X} 33$ & 0.484 & 0.1966 & VALID \\
\hline $\mathrm{X} 34$ & 0.549 & 0.1966 & VALID \\
\hline $\mathrm{S} 4 \mathrm{n}$
\end{tabular}

Sumber: hasil pengolahan data

Berdasarkan hasil uji reliabilitas diperoleh output Uji Reliabilitas yang tersaji dalam Gambar 2. Besaran koefisien Cronbach's Alpha menunjukkan angka 0.840 lebih besar dari 0.6 yang dapat diartikan bahwa instrumen kuesioner handal untuk digunakan dalam penelitian.
Tabel 3. Uji Reliabilitas

\begin{tabular}{|l|l|l|}
\hline & $\begin{array}{l}\text { Cronbach's } \\
\text { Alpha Based on } \\
\text { Standardized } \\
\text { Cronbach's } \\
\text { Alpha }\end{array}$ & N of Items \\
\hline .836 & .840 & 26 \\
\hline
\end{tabular}

Sumber: hasil pengolahan data

Berdasarkan hasil uji regresi linier berganda yang tersaji dalam Gambar 3, maka dapat diformulasikan rumus regresi sebagai berikut:

$$
\begin{aligned}
& \mathrm{Y}=2.195+0.109 \mathrm{X} 1+0.415 \mathrm{X} 2 \\
& +2.260 \times 3+\mathrm{e}
\end{aligned}
$$

Formulasi regresi linier berganda menunjukkan nilai-nilai koefisien dari masing-masing variabel independen. Variabel fasilitator manajemen (X1) memiliki koefisien sebesar 0,109 yang artinya apabila unsur variabel fasilitator manajemen dinaikkan intensitasnya sebanyak 1 poin, maka akan mampu meningkatkan eksistensi usaha mikro sebanyak 0.109. Variabel fasilitator pemasaran (X2) memiliki koefisien sebesar 0.415 yang artinya apabila unsur variabel fasilitator pemasaran dinaikkan intensitasnya sebanyak 1 poin, maka akan mampu meningkatkan eksistensi usaha mikro sebanyak 0.415. Sedangkan variabel fasilitator keuangan (X3) memiliki koefisien sebesar 2.260 yang artinya apabila unsur variabel fasilitator keuangan dinaikkan intensitasnya sebanyak 1 poin, maka akan mampu 
meningkatkan eksistensi usaha mikro sebanyak 2.260.

Uji hipotesis secara parsial dengan uji $\mathrm{t}$ dapat dibuktikan dengan melihat output pada Gambar 3. Tingkat signifikansi Variabel Fasilitator Manajemen (X1) sebesar 0.227, yang artinya bahwa hasil ini tidak mendukung hipotesis 1 (H1). Pada penelitian ini, Fasilitator Manajemen bagi pelaku usaha mikro tidak memberikan pengaruh terhadap usaha mereka. Penolakan hipotesis ini didukung oleh hasil penelitian Karay (2012) yang menyatakan bahwa variabel pendampingan memiliki nilai korelasi yang rendah terhadap pemberdayaan
UMK. Tingkat signifikansi Variabel Fasilitator Pemasaran (X2) sebesar 0.000, yang artinya bahwa hasil ini mendukung hipotesis 2 (H2). Sedangkat tingkat signifikansi Variabel Fasilitator Keuangan (X3) sebesar 0.087, yang artinya bahwa hasil ini mendukung hipotesis 3 (H3). Penerimaan hipotesis 2 dan hipotesis 3 dikuatkan pula oleh hasil penelitian Karay (2012) yang menyatakan bahwa variabel keuangan dan variabel pemasaran mempunyai peran atau pengaruh yang signifikan dan positif terhadap pemberdayaan UMK.

Tabel 4. Uji Regresi Berganda

\begin{tabular}{|c|c|c|c|c|c|c|}
\hline & \multirow[t]{2}{*}{ Model } & \multicolumn{2}{|c|}{$\begin{array}{l}\text { Unstandardized } \\
\text { Coefficients }\end{array}$} & \multirow{2}{*}{$\begin{array}{c}\begin{array}{c}\text { Standardized } \\
\text { Coefficients }\end{array} \\
\text { Beta }\end{array}$} & \multirow[t]{2}{*}{$\mathbf{t}$} & \multirow[t]{2}{*}{ Sig } \\
\hline & & $\mathrm{B}$ & Std. Error & & & \\
\hline \multirow[t]{4}{*}{1} & (Constant) & 2.195 & .959 & & 2.290 & .024 \\
\hline & $\begin{array}{l}\mathrm{X} 1 \quad=\quad \text { Fasilitator } \\
\text { Manajemen }\end{array}$ & .050 & .041 & .109 & 1.217 & .227 \\
\hline & $\mathrm{X} 2=$ Fasilitator Pemasaran & .216 & .049 & .415 & 4.398 & .000 \\
\hline & X3 = Fasilitator Keuangan & .118 & .068 & 2.260 & 1.729 & .087 \\
\hline
\end{tabular}

Sumber: hasil pengolahan data

Uji F Uji digunakan untuk membuktikan hipotesis secara simultan. Berdasarkan hasil output ANOVA pada Gambar 4 menunjukkan tingkat signifikansi sebesar 0.000 yang dapat diartikan bahwa seluruh variabel independen memiliki pengaruh simultan signifikan terhadap variabel dependen. Hasil ini mendukung hipotesis penelitian 4 (H4), yaitu Fasilitator Manajemen, Fasilitator Pemasaran, dan Fasilitator Keuangan berpengaruh signifikan terhadap eksistensi Usaha Mikro. 
Tabel 5. Uji Pengaruh Simultan

\begin{tabular}{|l|l|l|l|l|l|l|}
\hline \multicolumn{1}{|c|}{ Model } & Sum of Squares & df & Mean Square & \multicolumn{1}{c|}{ F } & \multicolumn{1}{c|}{ Sig. } \\
\hline 1 & Regression & 59.516 & 3 & 14.879 & 34.041 & $.000^{\mathrm{a}}$ \\
& Residual & 41.524 & 95 & .437 & & \\
& Total & 101.040 & 99 & & & \\
\hline
\end{tabular}

a. Predictors: (Constant), X3 = Fasilitator Keuangan, X1 = Fasilitator Manajemen, X2 = Fasilitator

b. Dependent Variable: $Y=$ Eksistensi Usaha Mikro

Sumber: hasil pengolahan data

Koefisien determinasi $\left(\mathrm{R}^{2}\right)$ berdasarkan output uji determinasi pada Gambar 5. menunjukkan bahwa nilai $\mathrm{R}$ Square $\left(\mathrm{R}^{2}\right)$ sebesar 0.589 yang berati bahwa dalam model regresi berganda untuk menjelaskan faktor yang mempengaruhi eksistensi usaha mikro dapat dijelaskan oleh variabel fasilitator manajemen, fasilitator pemasaran, dan fasilitator keuangan sebesar 58,9\%, dan sisanya sebesar $41,1 \%$ dijelaskan oleh variabel lain diluar variabel independen dalam penelitian ini.

Tabel 6. Uji Determinasi

\begin{tabular}{|l|l|l|l|l|}
\hline Model & \multicolumn{1}{|c|}{$\mathbf{R}$} & R Square & \multicolumn{1}{|c|}{$\begin{array}{c}\text { Adjusted R } \\
\text { Square }\end{array}$} & $\begin{array}{c}\text { Std. Error of } \\
\text { the Estimate }\end{array}$ \\
\hline 1 & $.767^{\mathrm{a}}$ & .589 & .572 & .66113 \\
\hline
\end{tabular}

a. Predictors: (Constant), X4 = Fasilitator Keuangan, X2 = Fasilitator Manajemen, X3 = Fasilitator Pemasaran, X1 = Penyediaan Dana

b. Dependent Variable: Y = Eksistensi Usaha Mikro Sumber: hasil pengolahan data

\section{PEMBAHASAN}

Hasil uji regresi berganda menunjukkan variabel fasilitator manajemen (X1) memiliki koefisien sebesar 0.109 yang artinya apabila unsur variabel fasilitator manajemen dinaikkan intensitasnya sebanyak 1 poin, maka akan mampu meningkatkan eksistensi usaha mikro sebanyak 0,109 . Variabel fasilitator pemasaran (X2) memiliki koefisien sebesar 0.415 yang artinya apabila unsur variabel fasilitator pemasaran dinaikkan intensitasnya sebanyak 1 poin, maka akan mampu meningkatkan eksistensi usaha mikro sebanyak 0,415 . Sedangkan variabel fasilitator keuangan (X3) memiliki koefisien sebesar 2.260 yang artinya apabila unsur variabel fasilitator keuangan dinaikkan intensitasnya sebanyak 1 poin, maka akan mampu meningkatkan eksistensi usaha mikro sebanyak 2,260.

Berdasarkan hasil di atas dapat disimpulkan bahwa di antara tiga variabel independen yang diusulkan dalam model, variabel fasilitator keuangan memiliki kontribusi atau pengaruh yang lebih besar daripada variabel fasilitator manajemen dan fasilitator pemasaran. Hal ini menunjukkan bahwa yang paling penting dan utama untuk diperhatikan dalam membina usaha mikro adalah pembinaan dari sisi keuangan. Kembali lagi pada latar belakang yang dipaparkan, bahwa masalah utama yang dihadapi oleh usaha mikro 
lebih pada persoalan pencatatan keuangan yang menyebabkan sulit untuk mendapatkan akses modal dari lembaga keuangan maupun perbankan.

\section{SIMPULAN DAN SARAN}

\section{Simpulan}

Berdasar hasil observasi lapangan, olah data, dan analisis hasil olah data dapat disimpulkan sebagai berikut:

a. Secara parsial, ketiga variabel independen memiliki pengaruh terhadap eksistensi usaha mikro, namun yang memiliki pengaruh signifikan dan kuat terhadap eksistensi usaha mikro adalah variabel fasilitator keuangan.

b. Secara simultan, ketiga variabel memiliki pengaruh signifikan terhadap eksistensi usaha mikro namun tidak terlalu besar pengaruhnya, yang artinya eksistensi usaha mikro bisa dijelaskan oleh faktor lain selain variabel yang diajukan dalam model penelitian ini.

\section{Saran}

Berdasarkan uji secara simultan menunjukkan bahwa kemungkinan besar eksistensi usaha mikro yang ditunjukkan dari kinerjanya dipengaruhi oleh variabelvariabel lain di luar variabel yang diajukan dalam penelitian ini, maka untuk penelitian kedepannya diharapkan bisa menambahkan variabel untuk mempertajam dalam analisis.

\section{DAFTAR PUSTAKA}

Ashari. 2006. Pedoman Praktis Memahami Laporan Keuangan. Yogyakarta: Penerbit Andi.

Hidayat, H. Saidatul. 2006. Peran Lembaga Keuangan Mikro Terhadap Prestasi Industri Kecil Rumah Tangga di
Kabupaten Merangin. Skripsi, tidak dipublikasikan. Universitas Andalas.

Indriantoro, Nur dan Bambang Supomo. 2014. Metodologi Penelitian Bisnis untuk Akuntansi \& Manajemen. Edisi 1. Cetakan ke-12. Yogyakarta: BPFE.

Karay, Jonathan Cosmus. 2012. Analisis

Peran Lembaga Keuangan Mikro terhadap Pemberdayaan Usaha Mikro Kecil di Kabupaten Jayapura (Studi Kasus BPR Nusa Intim Cabang Sentani). Jurnal Ekonomi dan Bisnis, Volume 2, 32-48. Retrieved:https://studylibid.com/doc/624 924

Kinnear, Thomas C, dan Taylor, James R. 2003. Riset Pemasaran. (Terjemahan oleh Thamrin). Edisi Tiga. Jakarta: Erlangga.

Singarimbun, Masri \& Sofyan Effendi. 2009. Metode Penelitian Survei (Edisi Revisi). Jakarta: PT Pustaka LP3ES.

\section{PROFIL SINGKAT}

Dila Damayanti, lahir di Blitar, 21 Januari 1986. Meraih gelar Sarjana Ekonomi (S.E.) bidang Manajemen dari Universitas Jember pada Tahun 2008. Gelar Magister Manajemen (M.M.) diperoleh pada Tahun 2010 dari Universitas Jember. Pada saat ini bekerja sebagai Dosen Tetap pada Sekolah Tinggi Ilmu Ekonomi Widya Wiwaha Yogyakarta. 